\title{
Information Needs for Climate Change Adaptation among Rural Farmers in Owerri West Local Area of Imo State, Nigeria
}

\author{
Umunakwe PC ${ }^{1 *}$, Nnadi FN ${ }^{1}$, Chikaire $\mathbf{J}^{1}$ and Nnadi $\mathbf{C D}^{2}$ \\ ${ }^{1}$ Department of Agricultural Extension, Federal University of Technology, P.M.B. 1526 Owerri Imo State, Nigeria \\ ${ }^{2}$ Department of Agricultural Economics and Rural Sociology, Niger Delta University, Wilberforce Island, Bayelsa State, Nigeria
}

\begin{abstract}
Information on climate risks communicated timely, in clear and relevant terms and through credible sources is essential for mobilizing decision makers across societies to take actions that will enhance their capacity and willingness to adapt to climate change. An informed public is better able to prepare for a likely occurrence of climate disaster and thus avert or cope with its attendant effects. The study analyzed information needs for climate change adaptation among rural farmers in Imo state, Nigeria. Specifically, it determined the socio-economic characteristics of the farmers, investigated their knowledge of climate change, identified their sources of information on climate change, identified their information needs for climate change adaptation and analyzed the socio-economic determinants of the farmers' needs for climate change adaptation. Data were elicited from 120 farmers using structured questionnaire and interview schedule. These were analyzed using percentages, bar charts and mean statistics. The hypothesis was analyzed using ordinary least square regression model at $0.05 \%$. Results revealed that majority $(95.1 \%)$ of the farmers described their knowledge of climate change as change in rainfall pattern. It also revealed that the farmers identified radio (61.6\%), extension agents (35.8\%) and newspaper (27.5\%) as their major sources of information on climate change. The result further revealed that the farmers identified effects of climate change $(M=4.15)$, causes of climate change $(M=4.06)$, vulnerable groups to climate change $(M=4.03)$, appropriate socio-cultural practices in climate change adaptation ( $M=3.99)$, crops adaptable to climate change $(M=3.96)$, sources of information on climate change $(M=3.93)$, agroforestry practices $(M=3.89)$, flood/erosion control practices $(M=3.85)$, afforestation practices $(\mathrm{M}=3.75)$, carbon trading $(\mathrm{M}=3.68)$ and adaptation strategies $(\mathrm{M}=3.34)$. The study recommended the organization of capacity building programmes relevant to agriculture, the timely generation and dissemination of information on climate change and the reviewing of extension curriculum to accommodate the training of extension personnel on climate change issues as strategies for enhancing adaptation to climate change.
\end{abstract}

Keywords: Information needs; Climate change; Adaptation; Rural farmers; Nigeria

\section{Introduction}

Climate change will have significant impacts on the livelihoods of rural poor in developing countries. The Intergovernmental Panel on Climate Change report 2007 provides an extensive assessment on the expected effects of climate change on agriculture in the African region. It estimates that Africa will be the most vulnerable to climate change globally, due to the increase by between $1.5-4.0^{\circ} \mathrm{C}$ in temperature in this century. Projections on yield reduction show a drop of up to $50 \%$ and crop revenue is forecast to fall by as much as $90 \%$ by 2100 . The agricultural sector is also expected to experience periods of prolonged droughts and/or flood during the El Nino events. Agricultural losses of between $2-7 \%$ of the GDP are expected by 2100 in parts of the Sahara, and $0.4 \%-1.3 \%$ and $2 * 4 \%$ in Western and Central Africa and Northern and Southern Africa respectively. Fisheries will be particularly affected due to changes in sea temperature that could decrease trends in productivity by $50-60 \%[1]$.

Furthermore, the Overseas Development Institute (2007) posits that productivity in agriculture will further be undermined by a reduction in fertile agricultural land availability and expansion in the coverage of low potential land [2]. More so, in response to variations in temperature and precipitation, Africa is expected to experience an increase in crop pests and diseases in addition to altered soil fertility. Declining income and rising unemployment are expected to hit agricultural zones in combination to worsening health. A fall in nutrient access is likely to raise susceptibility to diseases such as malaria and HIV/AIDS [3].
In Nigeria, analysis of climatic data collected by the Nigerian Meteorological Institute over several decades reveal that since the 1970s, most parts of Nigeria have experienced some shifts in weather patterns. For instance, in recent years, the average amount of rainfall has decreased by 15 to $20 \%$ while rainfall intensity has increased by about 10 to $15 \%$ leading to high surface runoff and frequent flooding, and soil erosion in various parts of the country. This has adversely affected crop yields while promoting the development and spread of pests. Complications arising from poor land use and land degradation further compound the problem [4-7].

The overall climate change poses a substantial challenge to Africa's agricultural development. From food security, nutrition to sustainable development, climate change is a significant threat to the welfare of millions of the continent's rural poor. Contending with this challenge therefore requires the development of intensive research and policy frameworks to enable the development of proper adaptation measures which will reduce the continent's vulnerability. This however is

*Corresponding author: Umunakwe, Department of Agricultural Extension, Federal University of Technology, P.M.B. 1526, Owerri Imo State, Nigeria, Tel: 08063639426; E-mail: polycarpchika@yahoo.com, limanchiks@gmail.com

Received November 21, 2013; Accepted January 25, 2014; Published January 28, 2014

Citation: Umunakwe PC, Nnadi FN, Chikaire J, Nnadi CD (2014) Information Needs for Climate Change Adaptation among Rural Farmers in Owerri West Local Area of Imo State, Nigeria. Agrotechnol 3: 118. doi:10.4172/2168-9881.1000118

Copyright: @ 2014 Umunakwe PC, et al. This is an open-access article distributed under the terms of the Creative Commons Attribution License, which permits unrestricted use, distribution, and reproduction in any medium, provided the original author and source are credited. 
dependent largely on the generation, dissemination and adoption of useful information on climate change.

According to the World Meteorological Organization (2011) climate information and prediction services enable better management of climate variability and change and adaptation through the incorporation of science-based practices into planning, policy and practices on the global, regional and national scale. Ilevbaje (1999) corroborates this by stressing that information is crucial in agricultural development. It also enables farmers to take decisions regarding their choice of practices in order to avert or reduce risks related to climate change and promote sustainable development [8-10].

While progress has been made in generating climate change information in sub-Saharan Africa majority of the African countries continue to suffer the full impacts of climate change [11]. Investigations conducted have revealed massive deficits in the transmission of early warning messages in highly vulnerable countries, where climate services where they exist are largely inaccessible to millions of rural poor whose livelihoods are climate-dependent [12]. This may be due to the fact that the largest demographic-the rural farmers-are cut off from the benefits of climate change information despite the designation of such groups as 'key targets' of such projects [13]. Yesuf et al. [14] reported the lack of information as the major adaptation constraint faced by farmers in Ethiopia.

A study conducted by GOZ-UNDP/GEF (2010) in Chiredzi district Zimbabwe revealed that majority of the farmers indicated that the information they received on climate change did not meet their needs because it was too generalized. They however indicated that they required information that would assist them in planting crops that are commonly grown in their area. However, the lack of the required information in climate change information received by the farmers rendered the entire information on climate change unreliable which affected adversely their productivity [15].

According to USAID (2007) appropriate interventions must incorporate disaster planning response and mitigation into governance systems and engage vulnerable groups into participatory fora to address their vulnerability and to identify adaptations to climate change impacts [16]. Sustainable adaptation should also allow for decision making from all stakeholders, including poor men and women and should incorporate site-specific information as the non-consideration of these factors might result to the rejection or slow adoption of such adaptation technologies. Furthermore, involvement of local community members enhances ownership and sustainability $[17,12]$ maintains that transmitting climate information to the grassroots level is one of the major challenges to making climate and weather information relevant to vulnerable communities. It is against this backdrop that the following research questions were asked:

$>$ What is the farmers' knowledge on climate change?

$>$ What are the farmers' sources of climate change information?

What are the farmers' perceived information needs for climate change adaptation? And

What are the socioeconomic determinants of farmers' needs for information on climate change.

\section{Objectives of the Study}

The broad objective of the study is to evaluate information needs for climate change adaptation among rural farmers in Imo State,
Nigeria. Specifically the study seeks to:

\section{Determine the socio-economic characteristics of farmers;}

II. Investigate the farmers' knowledge about climate change;

III. Identify farmers' sources of information about climate change;

IV. Identify the farmers' information needs for climate change; and

V. Analyse the socio-economic determinants of the farmers' information needs for climate change adaptation.

\section{Research Hypothesis}

There is no significant relationship between the socio-economic characteristics of the farmers and their information needs for climate change adaptation.

\section{Materials and Method}

The study was conducted in Owerri West local government area. It is in Imo East Senatorial zone and Owerri Agricultural zone of Imo State, Nigeria. It is also among the 27 local government areas in Imo State and has 18 autonomous communities with an estimated population of 101,754 people and a land size of 297, 127 square kilometer (National Population Commissions, 2006). It is located in the rainforest zone about $120 \mathrm{~km}$ north of the Atlantic coast and lies on latitude $4^{\circ} 14^{\prime}$ and $6^{\circ} 15^{\prime}$ and longitude $6^{\circ} 51^{\prime}$ and $8^{\circ} 09^{\prime}$ East. It is bounded in the east by Owerri North and Owerri Municipal Local Government Areas, in the north by Mbaitoli local government area, in the West by Ohaji/Egbema in the South by Ngor-Okpala Local Government Area.

The average annual rainfall measures up to $2550 \mathrm{~mm}$, the relative mean temperature ranges annually between $24.5^{\circ}$ and $25.5^{\circ} \mathrm{C}$ and the relative humidity varies according to the time of the year (ISADA, 2000). The people are predominantly farmers with cassava, cocoyam, yam, maize and vegetables and goats, sheep, poultry and pigs as major arable crops grown and livestock kept, respectively.

The population for the study comprised all farmers in the study area. Multi-stage sampling technique was used for sample selection. The first stage comprised the selection of six communities out of the 18 communities that make up the local government area using simple random sampling technique. The second stage was the selection of four villages from each of the six communities using simple random sampling technique to give a total of 24 villages. The third and final stage comprised the selection of five farmers from each of the 24 villages using simple random sampling technique giving a total of 120 farmers.

Data were obtained from both primary and secondary sources. Primary data were obtained with the aid of structured questionnaire and interview schedule from literate and illiterate farmers respectively in the study area while secondary data were obtained from annual reports of Imo state Agricultural Development Programme, Imo state Ministry of Petroleum and Environment, text books, journals, internet and previous studies of other researchers.

Descriptive and inferential statistical tools were used to analyze data. Objective 1 was analyzed using frequency and mean statistics. Objectives 2 and 3 were analyzed using bar chart. Objective 4 was analyzed using mean statistics. The hypothesis was analyzed using the Ordinary Least Square Multiple Regression implicitly represented by the equation:

$$
\mathrm{Y}=\mathrm{f}\left(\mathrm{X}_{1}+\mathrm{X}_{2}+\mathrm{X}_{3}+\mathrm{X}_{4}+\mathrm{X}_{5}+\mathrm{X}_{6}+\mathrm{X}_{7}+\mathrm{X}_{8}\right)+\mathrm{e}
$$


Citation: Umunakwe PC, Nnadi FN, Chikaire J, Nnadi CD (2014) Information Needs for Climate Change Adaptation among Rural Farmers in Owerri West Local Area of Imo State, Nigeria. Agrotechnol 3: 118. doi:10.4172/2168-9881.1000118

Page 3 of 6

Where $\mathrm{Y}=$ Sum total of areas of information needs indicated by the farmers

$$
\mathrm{X}_{1}=\text { Age (years) }
$$

$\mathrm{X}_{2}=\mathrm{Sex}$ (Using dummy, Female $=0$, Male $=1$ )

$\mathrm{X}_{3}=$ Marital Status (Single $=0$, Married=1, Separated or Divorced=2, Widowed $=3$ )

$\mathrm{X}_{4}=$ Farming experience (Years)

$\mathrm{X}_{5}=$ Educational level (No formal education $=0$, Primary School=1, Secondary School $=2$, Tertiary $=3$, others $=4$ ) pot)

$\mathrm{X}_{6}=$ Household size (Number of people that feed from the same

$\mathrm{X}_{7}=$ Farm size (Hectare)

$\mathrm{X}_{8}=$ Farming status (Part time $=0$, full time $=1$ )

$\mathrm{X}_{9}=$ Social organization membership (Yes $=1, \mathrm{No}=0$ )

The four functional forms of the model were tested and the one with the best fit; highest number of F-value, coefficient of multiple determinations (R2) and highest number of significant variables was chosen for the analysis.

\section{Results and Discussion}

\section{Socioeconomic characteristics}

Age: Data in Table 1 show that a greater proportion (46.7\%) of the farmers were within the age range of 40-49 years while the remaining $35.8 \%, 15.0 \%$ and $2.5 \%$ were within the age ranges of $50-59,30-39$ years and 60-69 years respectively. The mean age of the farmers was 47 years. This shows that the study area is dominated by relatively young farmers who are still within the economically active age. According to Agbamu [18] younger farmers are more likely to adopt agricultural innovations. However, this is contrary to the expectation that rural areas are dominated by old farmers as a result of rural-urban migration [19].

Sex: Data in Table 1 show that majority (59.17\%) of the respondents were female while the remaining $40.83 \%$ were male. This means that the study area was dominated by female farmers. This lays credence that the population of rural Nigeria is dominated by females [20]. This could be attributed to the increasing cases of migration of the male counterparts to cities in search of greener pastures and increasing incidence of female-headed households. As posited by Agarwala (2008) women occupy a significant proportion of agricultural labour force in developing countries and play very crucial roles in agricultural production [21].

Marital status: Data in Table 1 show that majority (80.83\%) of the farmers were married while the remaining $9.17 \%, 5.0 \%$ and $5.0 \%$ were widowed, single and divorced respectively. Married people are more likely to engage in farming activities to secure households from their requirements and complement their other sources of income. Marriage furnishes more hands for farming as parents and their progenies complement one another in agricultural production. This is in line with the finding of a study by Umunakwe [22] where majority of the farmers in Imo State were married.

Educational level: Data in Table 1 show that majority (98.3\%) of the farmers received one form of formal education or the other with $61.0 \%$ receiving secondary, $23.3 \%$ tertiary and $13.3 \%$ primary education. This is in line with the findings of where majority of the farmers interviewed in Delta state, Nigeria received formal education [19].

\begin{tabular}{|c|c|c|c|}
\hline Socioeconomic characteristic & Frequency & $\%$ & M \\
\hline \multicolumn{4}{|l|}{ Age (Years) } \\
\hline$<30$ & 0 & 0.0 & \\
\hline $30-39$ & 18 & 15.0 & \\
\hline $40-49$ & 56 & 46.7 & 47 \\
\hline $50-59$ & 43 & 35.8 & \\
\hline $60-69$ & 3 & 2.5 & \\
\hline$>69$ & 0 & 0.0 & \\
\hline \multicolumn{4}{|l|}{ Sex } \\
\hline Male & 49 & 40.83 & \\
\hline Female & 71 & 59.17 & \\
\hline \multicolumn{4}{|l|}{ Marital Status } \\
\hline Single & 6 & 5.0 & \\
\hline Married & 97 & 80.83 & \\
\hline Divorced & 6 & 5.0 & \\
\hline Widowed & 11 & 9.17 & \\
\hline \multicolumn{4}{|l|}{ Educational level } \\
\hline No formal education & 2 & 1.7 & \\
\hline Primary education & 16 & 13.3 & \\
\hline Secondary education & 74 & 61.7 & \\
\hline Tertiary education & 28 & 23.3 & \\
\hline \multicolumn{4}{|l|}{ Social organization membership } \\
\hline Ordinary member & 51 & 42.5 & \\
\hline Regular member & 38 & 31.7 & \\
\hline Financial member & 3 & 2.5 & \\
\hline Committee member & 21 & 17.5 & \\
\hline Executive member & 7 & 5.8 & \\
\hline \multicolumn{4}{|c|}{ Household size (Number of persons) } \\
\hline $1-3$ & 36 & 30.0 & \\
\hline $4-6$ & 73 & 60.8 & \\
\hline $7-9$ & 10 & 8.4 & 2 \\
\hline$>10$ & 1 & 0.8 & \\
\hline \multicolumn{4}{|l|}{ Farm size (Hectare) } \\
\hline$<1.0$ & 48 & 40.90 & \\
\hline $1.0-3.0$ & 60 & 50.0 & \\
\hline $3.0-5.0$ & 8 & 6.7 & \\
\hline$>5.1$ & 4 & 3.3 & \\
\hline \multicolumn{4}{|l|}{ Farming experience (Years) } \\
\hline$<10$ & 1 & 0.8 & \\
\hline $11-20$ & 39 & 31.8 & \\
\hline $21-30$ & 70 & 58.3 & 12.9 \\
\hline $31-40$ & 10 & 8.3 & \\
\hline$>40$ & 1 & 0.8 & \\
\hline \multicolumn{4}{|l|}{ Farming status } \\
\hline Full time & 104 & 86.7 & \\
\hline Part time & 16 & 13.3 & \\
\hline
\end{tabular}

Table 1: Distribution of respondents according to socioeconomic characteristics.

Acquisition of education influences the adoption of agricultural technologies by farmers. According to Agbamu [23], formal education enables farmers to obtain useful information from bulletins, agricultural newsletters and other sources. Ogunfiditimi [24] found that the level of education of farmers in Oyo and Ondo States, Nigeria yielded positive significant relationship to the adoption of improved varieties of cassava, maize and cocoa.

Social organization membership: Data in Table 1 show that all the respondents (100\%) are members of social organizations. Out of these $42.5 \%$ were ordinary members, $31.7 \%$ were regular members, $17.5 \%$ were committee members, $5.8 \%$ were executive members, while $2.5 \%$ were financial members. Membership of social organizations satisfied 
the farmers' social needs and furnished agricultural information which consequently led to adoption and diffusion.

The various statuses are reflective of their levels of commitment. According to Agbamu [18,23] Nigerian farmers belong to a number of social organizations and social or group meetings ranked third among the information sources to farmers in Ogun state, Nigeria.

Household size: Data in Table 1 reveal that majority $(60.8 \%)$ of the farmers had a household size of 4-6 people while the remaining $30 \%$, $8.4 \%$ and $0.8 \%$ had a household size of $1-3,7-9$ and more than 10 people, respectively. The mean household size was 2 persons. The consistent population campaign by governmental and non-governmental organizations, increasing economic crunch and influence of religion, especially Christianity may have been responsible for the low household size. Agriculture in developing countries is largely rudimentary and hence is characterized by low or no mechanization and this encourages the reliance on human power for farm operations especially the cheap human labour [20]

Farm size: Data in Table 1 show that majority (50.0\%) of the respondents have a farm size of 1-3 hectares while the remaining $40.00 \%, 6.7 \%$ and $3.3 \%$ have farm sizes of $<1.0,3-5$ and $>5.0$ hectares respectively. The mean farm size was 1.3 hectares. Farm lands in the traditional Igbo society are communally owned and this leads to fragmentation, leaving farmers with small farm sizes. Resultantly, most of the farmers in Southeastern Nigeria own farm lands that are hardly more than 1.0 hectare [20]. According to Williams et al. [25] the larger the farm business in terms of acreage the earlier the farmer tends to adopt those new technologies which are applicable to his farm business.

Farming experience: Data in Table 1 show that majority (58.3\%) of the farmers had been in farming business for 21-30 years while the remaining $31.8 \%, 8.3 \%, 0.8 \%$ and $0.8 \%$ have been in farming business for $11-20,31-40,<10$ and $>40$ years, respectively. The mean farming experience was 12.9 years. This means that the farmers have been into farming for relatively long periods. Many years of farming experience could entail much knowledge of the climatic, ecological and edaphic conditions of the area which are assets in climate change adaptation. The result corroborates the finding of a study by Nnadi et al. (2012) where majority of the farmers in Imo State had a long farming experience with a mean of.

Farming status: Data in Table 1 show that majority $(86.7 \%)$ of the farmers were into full time farming while the remaining $13.3 \%$ were into part time farming. This result means that majority of the farmers engage in farming as a major occupation and would therefore crave for much information to adapt to climate change to avert food insecurity. Ekong [20] described farming as a dominant activity in rural areas in Nigeria.

Knowledge of climate change: Data in Figure 1 show that majority (95.1\%) of the farmers describe climate change as a change in rainfall pattern while the remaining $24.16 \%, 17.5 \%, 11.6 \%$ and $9.16 \%$ know that climate change causes excessive rainfall, prolonged drought, over flooding and erosion. Analyses of climatic data collected by NIMET over several decades reveal that most parts of Nigeria have experienced some shift in weather patterns. For example, some parts of the country now have delay in the onset of rainfall. Also, many parts of the country recently experienced flooding as a result of excessive rainfall [26]. Knowledge and description of climate change is location-specific. However, it will enable the farmer to point out the interventions he requires to remedy the effects/impacts of climate change.

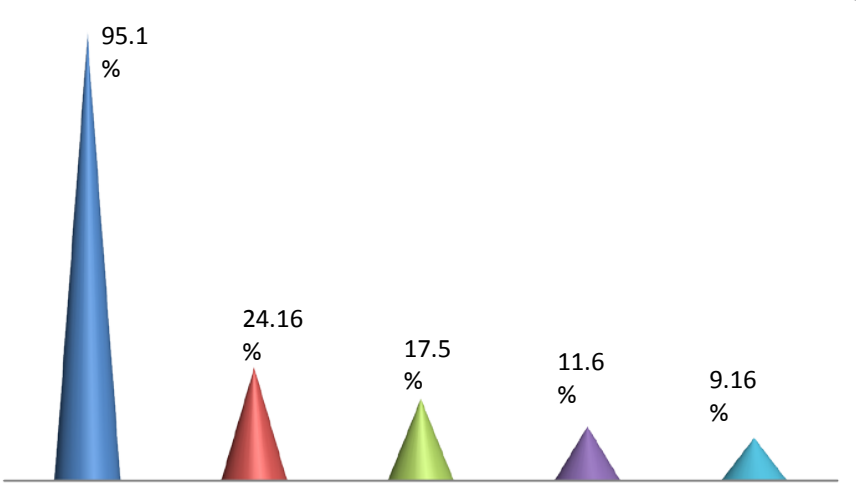

Figure 1: Distribution of farmers according to knowledge of climate change.

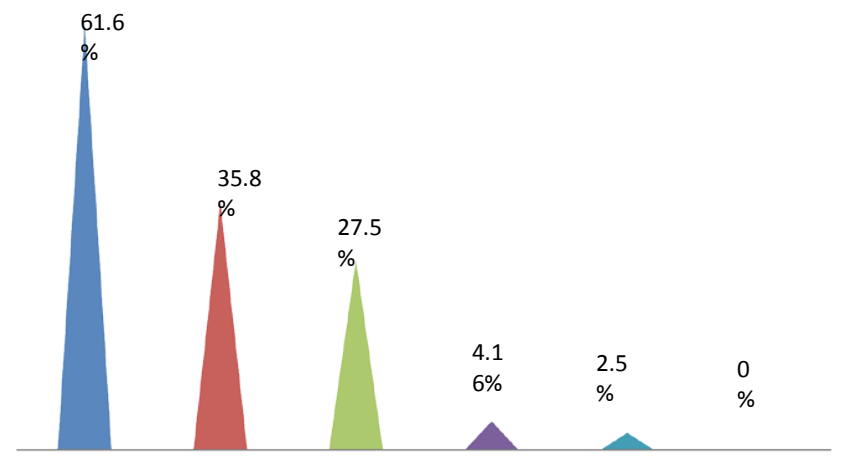

Figure 2: Distribution of farmers according to sources of information on climate change.

Sources of information on climate change: Data in Figure 2 reveal that majority $(61.6 \%)$ of the farmers received information on climate change through radio while the remaining $35.8 \%, 27.5 \%, 4.16 \%$ and $2.5 \%$ received information on climate change through extension agents, newspapers, research institutions and cooperative societies. According to GoZ-UNDP/GEF (2010) farmers in Zimbabwe relied mainly on radio, newspaper and extension agents for information on climate change. They however lamented that the high cost of newspapers and the fewness of extension agents constrained their access to climate change adaptation information [15].

Timely reception of climate change information will enable farmers take necessary measures to avert or cope with impending impacts/effects of climate change. According to United Nations (2009) early warning system is crucial for preparedness for extreme weather events [27].

Areas of information need for climate change adaptation: Data in Table 2 below show that farmers indicated that they needed information on the effects of climate change $(M=4.15)$, causes of climate change $(M=4.06)$, vulnerable groups to climate change $(M=4.03)$, appropriate socio-cultural practices in climate change $(M=3.99)$, crops adaptable to climate change $(\mathrm{M}=3.96)$, sources of information on climate change $(M=3.93)$, agroforestry practices $(M=3.89)$, flood/ erosion control practices $(M=3.85)$, afforestation practices $(M=3.75)$, carbon trading $(\mathrm{M}=3.68)$ and adaptation strategies $(\mathrm{M}=3.34)$. A study conducted in the Chiredzi District, Zimbabwe revealed that farmers interviewed indicated that they needed information to assist them in planting the different crops that are commonly grown, information on rainfall pattern, time of occurrence of the mid-season drought or dry spells and flooding and storm warnings [15]. 


\begin{tabular}{|l|c|}
\hline Areas of information need & M \\
\hline Causes of climate change & 4.06 \\
\hline Effects of climate change & 4.15 \\
\hline Sources of information on climate change & 3.93 \\
\hline Crops adaptable to climate change & 3.96 \\
\hline Appropriate socio-cultural practices in climate change & 3.99 \\
\hline Agroforestry practices & 3.89 \\
\hline Flood/erosion control practices & 3.85 \\
\hline Afforestation practices & 3.75 \\
\hline Carbon trading & 3.68 \\
\hline Alternative/complementary livelihood activities & 2.93 \\
\hline Adaptation strategies & 3.34 \\
\hline Vulnerable groups to climate change & 4.03 \\
\hline
\end{tabular}

Table 2: Distribution of farmers according to information needs for climate change adaptation.

\begin{tabular}{|c|c|c|c|c|}
\hline $\begin{array}{l}\text { Explanatory } \\
\text { variables }\end{array}$ & $\begin{array}{l}\text { Linear } \\
\text { function }\end{array}$ & $\begin{array}{l}\text { Semi-log } \\
\text { function }\end{array}$ & $\begin{array}{l}\text { Double-log } \\
\text { function }\end{array}$ & $\begin{array}{l}\text { Exponential } \\
\text { function }\end{array}$ \\
\hline Constant & 188.3992 & 143.0832 & 129.8117 & 118.201 \\
\hline R2 & 0.4993 & 0.4028 & 0.8013 & 0.5618 \\
\hline No. of observation & 120 & 120 & 120 & 120 \\
\hline Degrees of freedom & 119 & 119 & 119 & 119 \\
\hline F-Value & 12.6004 & 8.2423 & 49.4629 & $\begin{array}{l}16.0057 \\
(-0.0079)\end{array}$ \\
\hline $\mathrm{X}_{1}$ (Age) & $\begin{array}{l}-15.0821 \\
(-1.0684)\end{array}$ & $\begin{array}{l}8.2423 \\
(-1.1212)\end{array}$ & $\begin{array}{l}-0.0665 \\
(-2.7824)^{*}\end{array}$ & $\begin{array}{l}-0.0079 \\
(-1.2344)\end{array}$ \\
\hline $\mathrm{X}_{2}$ (Sex) & $\begin{array}{l}16.3913 \\
(1.0845)\end{array}$ & $\begin{array}{l}1.4107 \\
(1.0136)\end{array}$ & $\begin{array}{l}0.0638 \\
(1.0687)\end{array}$ & $\begin{array}{l}0.0053 \\
(1.1277)\end{array}$ \\
\hline $\mathrm{X}_{3}$ (Marital status) & $\begin{array}{l}18.2271 \\
(1.0706)\end{array}$ & $\begin{array}{l}1.5525 \\
(1.0624)\end{array}$ & $\begin{array}{l}0.0544 \\
(1.3432)\end{array}$ & $\begin{array}{l}0.0091 \\
(3.9565)^{\star}\end{array}$ \\
\hline $\mathrm{X}_{4}$ (Farming experience) & $\begin{array}{l}7.8827 \\
(3.7684)^{*}\end{array}$ & $\begin{array}{l}1.5912 \\
(3.9494)^{*}\end{array}$ & $\begin{array}{l}0.0717 \\
(3.1726)^{*}\end{array}$ & $\begin{array}{l}0.0054 \\
(2.8421)^{\star}\end{array}$ \\
\hline $\mathrm{X}_{5}$ (Educational level) & $\begin{array}{l}-73116 \\
(-1.1647)\end{array}$ & $\begin{array}{l}-3.7754 \\
(-1.2591)\end{array}$ & $\begin{array}{l}-1.0843 \\
(-4.0725)^{*}\end{array}$ & $\begin{array}{l}-0.0087 \\
(-3.7826)^{*}\end{array}$ \\
\hline $\mathrm{X}_{6}($ Household size $)$ & $\begin{array}{l}8.2107 \\
(3.2951)^{*}\end{array}$ & $\begin{array}{l}2.1793 \\
(1.0690)\end{array}$ & $\begin{array}{l}0.0729 \\
(3.344)^{\star}\end{array}$ & $\begin{array}{l}0.0083 \\
(1.1526)\end{array}$ \\
\hline $\mathrm{X}_{7}$ (Farm size) & $\begin{array}{l}5.9278 \\
(1.2238)\end{array}$ & $\begin{array}{l}1.9602 \\
(1.1142)\end{array}$ & $\begin{array}{l}0.0527 \\
(2.6616)^{*}\end{array}$ & $\begin{array}{l}0.0068 \\
(1.1526)\end{array}$ \\
\hline $\mathrm{X}_{8}$ (Farming status) & $\begin{array}{l}10.0806 \\
(1.1061)\end{array}$ & $\begin{array}{l}2.1843 \\
(1.0420)\end{array}$ & $\begin{array}{l}0.0692 \\
(3.2488)^{*}\end{array}$ & $\begin{array}{l}0.0082 \\
(2.6452)^{*}\end{array}$ \\
\hline $\begin{array}{l}X_{9} \text { (Social organization } \\
\text { membership) }\end{array}$ & $\begin{array}{l}13.1314 \\
(3.2143)^{*}\end{array}$ & $\begin{array}{l}3.0749 \\
(3.0499)^{*}\end{array}$ & $\begin{array}{l}0.9140 \\
(3.0671)^{*}\end{array}$ & $\begin{array}{l}0.0792 \\
(2.5631)^{*}\end{array}$ \\
\hline
\end{tabular}

\section{*significant}

Table 3: Regression result of the relationship between the farmers' socio-economic characteristics and their information needs for climate change adaptation.

The timely availability of this information to the farmers will enable them make certain decisions pertaining their farming business such as the types of crops to grow, when to grow them, when to weed and apply fertilizer and harvest, when to apply herbicides and when to cull livestock. The knowledge of the type of information required by the farmers will guide researchers in the development of suitable adaptation strategies [28-30].

\section{Hypothesis}

There is no significant relationship between the socio-economic characteristics of the farmers and their information needs for climate change adaptation.

\section{Socioeconomic determinants of farmers' information needs for climate change adaptation}

The result in Table 3 shows that Double Log Function had the highest number of significant variables (six) and coefficient of multiple determination R2 (0.08013) and F-value (49.4629). Thus, it serves as the lead equation for the explanation of the relationship.

The result shows that there was a significant relationship between socioeconomic characteristics of the farmers and the areas of information needs for climate change adaptation. The result implies that the combined effects of the variables accounted for $80 \%$ variation in the number of areas of information need by the farmers for climate change adaptation. The significant variables were age, educational level, household size, social organization membership, farm size, farming status and farming experience [31].

The variables, age $\left(\mathrm{X}_{1}\right)$ and educational level $\left(\mathrm{X}_{5}\right)$ were significant negatively related to the farmers' information needs for climate change adaptation with $t$-values of -2.7824 and -4.0725 , respectively. These imply that increasing the age and educational level reduced the farmers' need for information for climate change adaptation. Older farmers have been associated with fatalism, conservation and maintenance of status quo [19] and these attributes do not support innovativeness and quest for information. Education on the other hand furnishes facts and may equip the farmers with the right cognitive domain to analyze and understand climate change. The result agrees with the finding of Agbamu et al. [23] that negative but significant relationship existed between educational level of farmers and their adoption off TMS cassava and TZSR maize varieties.

Farming experience $\left(\mathrm{X}_{4}\right)$, household size $\left(\mathrm{X}_{6}\right)$, farm size $\left(\mathrm{X}_{7}\right)$, farming status $\left(\mathrm{X}_{8}\right)$ and membership of social organizations $\left(\mathrm{X}_{9}\right)$ were positively and significantly related to the farmers' information needs for climate change adaptation. Several years of farming experience would broaden farmers' knowledge base and consequently inspire their desire for more information on climate change. Large household size entails more pressure on the household for food security and this could incite the need for more information. Again, each member of the farm family is a stakeholder in the farming business and as such is a potential source of information on climate change. The aggregate information need may not be comparable to that of a small household. A large farm size means a big farm investment and this is real business. Increasing the information need consequently sharpens decision making for profitability.

Increasing farming status by part time farmers becoming full time and increase farm investible fund through increased commitment and interest in the business. This could arouse the desire for more information for profitable farm decisions. In the same vein, social organizations produce fora for exchange of agricultural information and some of the information could motivate the search for more especially for a critical issue like climate change adaptation.

However, the variables sex $\left(\mathrm{X}_{2}\right)$ and marital status $\left(\mathrm{X}_{3}\right)$ were not significantly related to the information needs of the farmers for climate change adaptation. They are inconsequential and as such do not exert any significant effects $[32,33]$.

\section{Conclusion}

Adaptation to climate change has remained a viable option for dealing with the impacts and effects of climate change. However, this will remain ineffective and unsustainable without the timely generation and dissemination of useful information on climate change to the people whose livelihoods are mostly affected. This as it has been pointed out will enhance the making the necessary decisions aimed at the reducing the impacts. 
Citation: Umunakwe PC, Nnadi FN, Chikaire J, Nnadi CD (2014) Information Needs for Climate Change Adaptation among Rural Farmers in Owerri West Local Area of Imo State, Nigeria. Agrotechnol 3: 118. doi:10.4172/2168-9881.1000118

Page 6 of 6

The findings from the study indicated that farmers in Nigeria needed information on mitigation issues for easy adaptation to climate change, obtained from diverse information sources. These are determined by the socio-economic characteristics of age, farming experience, educational level, farm size, farming status, household size and membership of social organizations.

From the foregoing, the study makes the following recommendations:

- Capacity building programmes relevant to climate change and agriculture should be organized by the government at all levels through the appropriate ministries, agencies and departments to train extension agents and educate farmers to boost their capacities for effective and sustainable adaptation to climate change;

- Takeholders in the generation of climate change information such as the Nigerian Meteorological Institute (NIMET) should ensure the timely generation and dissemination of relevant information on climate change (e.g. weather forecast) which should cover all the areas of need indicated by the farmers to enable them make decisions which will enhance their adaptation to climate change;

- Curriculum for training prospective extension personnel should be reviewed to incorporate the identified areas of information need for adaptation to climate change; and

- Interventions and advocacies in climate change should be guided by the identified socio-economic characteristics that determine the information needs for proper adaptation.

\section{References}

1. Parry ML, Canziani OF, Palutikof JP, van der Linden PJ, Hanson CE (2007) IPCC, Climate change 2007: Impacts, adaptation andvulnerability. Contributions of Working Group II to the Fourth Assessment Report of the Intergovernmental Panel on Climate Change. Cambridge: Cambridge University Press.

2. Rachel S, Leo P, Eva L, David B (2007)Climate change, agricultural policy and poverty reduction: How much do we know? Overseas Development Institute.

3. Food and Agricultural Organization (2009) Food security and agricultural mitigation in developing countries: Options for capturing synergies. FAO, Rome.

4. Apata TG(2010) Effects of global climate change on Nigerian agriculture: An empirical analysis.CBN Journal of Applied Statistics 2: 29-31.

5. Adejuwon JO (2006) Food crop production in Nigeria II: Potential effects of climate change. Climate Research 32: 229-245.

6. Adger WN, Huq S, Brown K, Conway D and Hulme M (2003) Adaptation to climate change in the developing world. Progress in Development Studies 3: 11-17.

7. Agbamu JU (2000) Agricultural Research-Extension Linkage Systems: An International Perspective, Agricultural and Extension and Research Network (Agren). Network Paper 3: 1-24

8. Smith RE (2003) Land tenure reform in Africa: A shift to the defensive. Progress in Development Studies 3: 210-222.

9. World Meteorological Institute (2007) Climate information for adaptation and development needs. WMO1025

10. Lyon F (2000) Trust, networks and norms: The creation of social capital in agricultural economies in Ghana. World Development 28: 663-681.

11. Tarhule A (2005) Climate information for development: An integrated dissemination model $11^{\text {th }}$ General Assembly of the Council for the Development of Social Research in Africa (CODESRIA) in Maputo. Mozambique.

12. Lugon $R$ (2010) Climate information for decision-making: Lessons learned from effective user-provider communication schemes. The Graduate Institute Centre for International Governance, Geneva.

13. Ogallo L (2007) CLIPS: RCOFs, Regional networking and consensus building and use liaison for targeted climate service delivery presented at the Public Weather Services Symposium. Geneva, Switzerland.

14. Yesuf M, Di Falco S, Deressa T, Ringler C and kohlin G (2008) The impact of climate change and adaptation on food production in low-income countries: Evidence from the Nile Basin, Ethiopia. International Food Policy Research Institute, IFPRI.

15. GoZ-UNDP/GEF (2010) Capacity needs assessment and strategy for enhanced use of seasonal climate forecasts for small-holder farmers in Chiredzi District, Zimbabwe. Environmental Management Agency, Harare, Zimbabwe.

16. United States Agency for International Development (2007) Adapting to climate variability and change: A guidance manual for development planning. USAID and Stratus Consulting, Washington.

17. Holmes P (1996) Building capacity for environmental management in Hong Kong. Water Resources Development 12: 461-472.

18. Agbamu JU (2006) Essentials of agricultural communication in Nigeria. Lagos: Malthouse Press Limited 203.

19. Ozor, Nicholas, Madukwe MC, Enete AA, Amaechian EC, et al. (2010) Barriers to climate change adaptation among farming households of Southern Nigeria. Journal of Agricultural Extension 14.

20. Ekong EE (2003) Introduction to rural sociology, Uyo: Dove Publications Itd.

21. Agarwala B (2008) Food security, productivity and gender inequality. IEG Working Paper No 314.

22. Umunakwe PC (2011) Strategies for climate change adaptation among rura households in Imo State, Nigeria.

23. Agbamu JU, Fujita Y, Idowu I, Lawal A (1996) Effects of socio-economic factors on adoption of new varieties of maize and cassava: A case study of Ogun State in Nigeria. Journal of Agricultural Development Studies 6.

24. Ogunfiditimi TO (1981) Adoption of improved farm practices: A choice under uncertainty. Indian Journal of Agricultural Extension Education 17.

25. William SKT, Fenley JM, Willaims CE (1984) A manual for agricultural extension workers in Nigeria. Ibadan: Less Shyraden Publishers, Nigeria.

26. Anuforom A (2012) Climate change and the challenge of environmenta management and technological development. Lecture delivered at the 25th convocation of the Federal University of Technology, Owerri, Nigeria.

27. United Nations (2009) Guidance on water and adaptation to climate change. United Nations, New York and Geneva.

28. Benhin JKA (2006) Climate change and South African Agriculture: Impacts and adaptation options. CEEPA Discussion Paper No 21.

29. Bryceson DF (2004) Agrarian vista or vortex: African rural livelihood policies. Review of African Political Economy 31: 617-629.

30. Jotoafrika (2009) Managing Africa's water in a changing climate. Issue 2.

31. Osman-Elasha B, Goubti N, Spanger-Siegfried E, Dougherty W, Hanafi A, et al. (2006) Adaptation strategies to increase human resilience against climate variability and change: Lessons from the Arid Regions of Sudan. AIACC Working Paper 42: 44.

32. Roncoli C, Okoba B, Gathaara V, Ngugi J and Nganga T (2010) Adaptation to climate change for smallholder agriculture in Kenya: Community-Based perspectives from five districts.

33. United States Department for International Development (2007) Adapting to climate variability and change. A guidance manual for development planning USAID Washington DC. 